\section{Predictors of financial satisfaction and its impact on psychological wellbeing of individuals}

\author{
Godfred Matthew Yaw Owusu \\ Department of Accounting, University of Ghana Business School, Accra, Ghana
}

Predictors of financial satisfaction

\begin{abstract}
Purpose - In this study, the author examines the effect of financial knowledge, financial attitude and responsible financial management behaviour on financial satisfaction and investigates the association between financial satisfaction and psychological wellbeing of individuals. The author examines these relationships having controlled for the influence of key demographic variables including age, gender, marital status, income level and employment status of respondents on the predicted relationships.

Design/methodology/approach - Data was gathered by means of a self-administered questionnaire to postgraduate business students from a large public university in Ghana. The hypothesized relationships of the study were tested using the Partial Least Square Structural Equation Modelling (PLS-SEM) technique.

Findings - The author shows from the structural model analysis using the bootstrapping procedure that financial knowledge, financial attitude and sound financial management behaviour have important implications on financial satisfaction levels of individuals. Further, the author finds financial satisfaction to be an important predictor of the psychological wellbeing of individuals.

Practical implications - The paper highlights the relevance of financial satisfaction on the psychological wellbeing of an individual and identifies some of the dominant factors that are associated with financial satisfaction. Originality/value - This study examines the concept of financial satisfaction at the individual level and uniquely highlights the psychological implications of financial satisfaction.
\end{abstract}

Keywords Structural equation modelling, Financial management, Psychological wellbeing, Financial satisfaction

Paper type Research paper

\section{Introduction}

Happiness and life satisfaction have been the most sought-after aspirations of individuals around the world. Indeed, available evidence in extant studies suggests that despite the improvement in the general quality of life of a considerable number of individuals over the years, many individuals continue to aspire to higher levels of satisfaction in life and greater happiness (Ingrid et al., 2009; Oishi et al., 2009; Plouffe and Tremblay, 2017). One of the major sources of happiness and life satisfaction as identified in literature is financial satisfaction (Ingrid et al., 2009). Owing to this, individuals are impelled to work for longer periods with the intention of earning more income to be financially satisfied. While the International Labour Organization (ILO) recommends a standard 40-h working week as established in Convention No. 47, most recent statistics suggest that, globally, the average weekly working time is far in excess of the recommended threshold (ILO, 2018). Indeed, a number of employees from many parts of the world work for much longer hours than recommended and it has been observed that huge variations exist in the distribution of normal working hours across countries.

(C) Godfred Matthew Yaw Owusu. Published in Journal of Humanities and Applied Social Sciences. Published by Emerald Publishing Limited. This article is published under the Creative Commons Attribution (CCBY 4.0) licence. Anyone may reproduce, distribute, translate and create derivative works of this article (for both commercial and non-commercial purposes), subject to full attribution to the original publication and authors. The full terms of this licence may be seen at http://creativecommons. org/licences/by/4.0/legalcode

Funding: This study was funded by the University of Ghana Business School Faculty Research Grant.
Received 30 May 2021 Revised 27 August 2021 3 September 2021 Accepted 9 September 2021

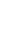


JHASS

5,1

60
The percentage of workers working for very long hours, defined as $60 \mathrm{~h}$ a week or more by the report (ILO, 2018) suggests Eastern Asia has the highest reported percentage of workers working over $60 \mathrm{~h}$ a week. This is distantly followed by sub-Saharan Africa, Central, Western and southern Asia, while close to $80 \%$ of countries in the Middle East permit weekly working hours in excess of $60 \mathrm{~h}$. Undoubtedly, the desire to work for longer working hours by individuals in many parts of the world is to improve the earning capacity of these individuals in order to afford some reasonable amount of comfort in life. While the quality of life of an individual has been described as a multifaceted concept comprising various indicators, the financial situation of an individual has been found to be a critical determinant of the quality of life in general. This, in part, explains why studies into financial satisfaction have been on the ascendency in recent times. Existing studies on financial satisfaction have, however, focused on the factors that influence financial satisfaction of the family as a unit. Factors including the income level, employment status, age differences and marital status have been found to be associated with the level of financial satisfaction (Fan and Babiarz, 2019; Joo and Grable, 2004; Kalra Sahi, 2013).

The current study examines the concept of financial satisfaction at the individual level, exploring the dominant predictors of financial satisfaction of individuals. Unlike the evidence provided by most extant studies, I examine an outcome of financial satisfaction by investigating its effect on the psychological wellbeing of individuals. By means of a structural model analysis, I specifically examine the effect of financial knowledge, financial attitude and financial management practices on financial satisfaction and ascertain whether financial satisfaction impacts positively on an individual's psychological wellbeing. Results of the structural model analysis, having controlled for the effect of age, gender, marital status, income level and employment status of respondents, indicate that financial knowledge, financial attitude and a sound financial management behaviour are key in achieving financial satisfaction. Additionally, I find financial satisfaction to be an important predictor of psychological wellbeing of individuals. The remaining sections of the paper are structured as follows; the next section contains the literature review and the hypotheses development, followed by the methodology section. The subsequent section discusses results followed by concluding remarks.

\section{Literature review}

\section{The concept of psychological well-being}

For aeons, the concept of happiness has been of great concern to individuals around the world. While some individuals question the sources of happiness, others have resolved to make themselves happy no matter what it takes. By nature, all humans desire to be happy, this being the ultimate goal of human desires and passion and by far the highest target of human existence. Notwithstanding the fact that the average individual aspires to be happy in life, empirical studies have shown that most individuals are not happy in life. This, in part, has been attributed to the fact that the meaning of happiness is often misplaced, especially with regards to what real happiness is (Xiao et al., 2009). While most individuals view happiness as the joy that we feel when striving to achieve our potential (Anic and Tončić, 2013), a considerable number of individuals also believe that happiness comes when one feels satisfied and fulfilled. Despite the varied views on the definition for happiness, social psychologists suggest that happiness is underpinned by one broad concept, "Wellbeing".

In broad terms, wellbeing encompasses the general condition of an individual. Extant literature has categorized the concept of wellbeing of an individual into objective and subjective components (Zemtsov et al., 2015). Whereas objective wellbeing is mainly concerned with the happenings in the external environment with respect to the living standards of the whole population of a country, subjective wellbeing focuses mainly on the 
individual traits and characteristics of each person. Subjective wellbeing of an individual consists of different dimensions including the physical, psychological, social and financial wellbeing. While the relevance of each dimension cannot be overemphasized, Vlaev and Elliott (2013) argue that the psychological wellbeing of an individual is fundamental to the overall wellbeing of an individual. Not only does the psychological wellbeing play a vital role in the personality and development of individuals, it also helps individuals to deal with challenges and achieve what they want in life.

Psychological wellbeing is simply "a generalized feeling of happiness” (Blatný and Šolcová,

Predictors of financial satisfaction 2016, p. 551). According to Hernandez et al. (2018), psychological wellbeing consists of a broad array of positively toned subjective states and cognitive appraisals including lower activation affects (e.g. calm or satisfied) and higher activation affects such as excited or thrilled. As a multidimensional construct, psychological wellbeing consists of several aspects including life satisfaction, self-acceptance (that is, positive evaluation of ones' self and ones' past life), personal growth (sustained growth and development of a person) and environmental mastery (the ability to effectively manage one's life as well as the surrounding world) (Carmeli et al., 2009). The above-mentioned dimensions of psychological wellbeing are tagged in most empirical studies as "positive functioning of psychological wellbeing” (Ryff and Singer, 1996; Zika and Chamberlain, 1992). In practice however, researchers often adopt one of these dimensions as a proxy for measuring overall psychological wellbeing.

Other forms of psychological wellbeing, other than the aforementioned ones, have been proposed by some researchers. The Hopkins Symptom Checklist (HSCL), for instance, has been employed in some studies. The HSCL is based on a four underlying symptom dimension, which include somatization (reflecting distress arising from perceptions of bodily dysfunction), obsessive-compulsive (focusing on thoughts, impulses and actions that are experienced as unremitting and irresistible by the individual), interpersonal sensitivity (focusing on feelings of personal inadequacy and inferiority, particularly in comparison to other persons) and anxiety and depression (Derogatis et al., 1974).

Extant studies have examined the dominant factors that influence psychological wellbeing. For instance, Lester et al. (1983) examined the relationship between Maslow's hierarchy of needs and psychological health and found that the fulfilment of each of the needs improved the psychological wellbeing of the individual. Their results show that the higher the level of satisfaction among the needs, the more psychologically healthier an individual becomes. The link between financial satisfaction and psychological wellbeing, however, remains an open question. This study examines the concept of financial satisfaction and ascertains whether it may be directly associated with the psychological wellbeing of individuals.

\section{Financial satisfaction}

The quality of life of an individual is a multifaceted concept comprising various domains in life. It encompasses life satisfaction, good physical and psychological health, personal expectations of one's goal in life and level of education, among others (Felce and Perry, 1995). Life satisfaction is considered the most valued aspect of quality of life and, as such, individuals continue to find ways of improving their living standards to feel satisfied in life (Parrotta and Johnson, 1998). Extant literature has shown that defining life satisfaction is subjective as it considers an individual's evaluations of life with respect to what the individual personally feels (Sam et al., 2015). Empirically, several factors have been found to be closely related to life satisfaction (Kim and Chatterjee, 2019; Korankye and Kalenkoski, 2021). One of the major determinants of life satisfaction and quality of life is satisfaction with one's financial status (Fan and Babiarz, 2019; Ng and Diener, 2014). A survey conducted to assess the quality of life of families in the United States suggests that even when times are 
JHASS 5,1

favourable, the fears and concerns of individuals are centred largely on financial matters (Erskine, 1973). Financial satisfaction is defined as the subjective evaluation of the extent to which one's financial resources are adequate or inadequate to meet both current and future financial obligations (Hira and Mugenda, 1998).

Extant studies have measured financial satisfaction in two different ways. While some studies adopt several indicator item scales, it is common to find just one item indicator such as satisfaction with income, satisfaction with current financial status and satisfaction with standard of living among others as useful measures of financial satisfaction (Ali et al., 2015; Vera-Toscano et al.,2006). Ali et al. (2015) suggest that out of the various indicators used in the measurement of financial satisfaction, satisfaction with financial status is arguably the broadest measure highlighting the overall financial situation of an individual.

In terms of its determinants, some demographic factors such as income levels have been associated with the financial satisfaction of individuals (Vera-Toscano et al., 2006; Seghieri et al., 2006). A high-income level is usually associated with a higher level of financial satisfaction as individuals within higher income bracket are able to meet their needs to a very large extent. Seghieri et al. (2006) suggest that a higher standard of satisfaction is achieved when a considerable number of needs are met as a result of a higher level of income. It has also been documented that financial satisfaction usually increases with age. Thus, older folks tend to be more financially satisfied than younger ones. The argument in support of this is that as individuals grow older, major expenditures are taken care of which relieves the individual of huge financial burdens and responsibilities. According to Hansen et al. (2008), a considerable part of the higher financial satisfaction with increasing age can be explained by greater assets and less debt among the aged. Hansen et al. (2008), however, admit that this assumption is relative as some people might still have their children and spouses to take care of as they age, which could affect their financial position. Indeed, Fan and Babiarz (2019) find financial satisfaction to peak at the youthful age and decline afterwards.

The effect of marital status on financial satisfaction has also received some research attention. Fan and Babiarz (2019), for instance, conclude that married people experience higher financial satisfaction than their single counterparts, and some studies have found employed individuals to experience higher financial satisfaction than the unemployed (Hong and Swanson, 1995; Joo and Grable, 2004). This finding indirectly supports the reported relationship between income levels and financial satisfaction given that the earning capacity of individuals in employment is undoubtedly higher than the unemployed.

Apart from these demographic variables, the influence of attitudes and behaviours on financial has also been highlighted in literature as key determinants of financial satisfaction. They include financial knowledge, financial attitude and financial management among others.

\section{Determinants of financial satisfaction}

Financial knowledge. Decision-making is an integral part of the life of an individual, the firm and government. The ability to make rational or sound decisions rests, in part, with the knowledge level of the individual as far as the subject matter is concern. One of the most important decisions that an individual is confronted with consistently at various stages in the life are the financial decisions. Undeniably, good financial decisions are made when individuals have the requisite financial knowledge (Huston, 2010). In the literature, the terms financial knowledge and financial literacy have often been used interchangeably (Huston, 2010, p. 296). While some researchers consider financial literacy as a broad concept encompassing financial knowledge, financial experience and financial behaviour, others conclude that both financial knowledge and financial literacy have a mutual meaning. Bowen (2002, p. 93), for instance, defines financial knowledge as "understanding key financial 
terms and concepts" needed to make well-informed financial decisions'. Servon and Kaestner (2008), on the other hand, attribute this same definition of financial knowledge to mean financial literacy. This study subscribes to conceptualization of financial knowledge to mean the understanding of important finance terms and concepts such as savings, insurance policies, budgeting and investment.

Over the years, studies on financial knowledge have explored the key drivers of focusing on the demographic factors as gender, age, social class and marital status among others (Joo and Grable, 2004; Parrotta and Johnson, 1998; Xiao and Porto, 2017). For instance, in terms of gender, studies have shown that men are more financially knowledgeable than women. This has been attributed to the fact that men have more opportunities as well as experience with formal financial services; hence, their knowledge in financial issues is higher than that of women (Chowa et al., 2012). In terms of outcomes, financial knowledge has been associated with several economic behaviours including retirement planning, wealth accumulation and financial wellbeing among others. The narrative is that the economic behaviour of individuals improves with increased financial knowledge.

Financial attitude. Eagly and Chaiken (1993) define attitude as a tendency to act in a good or favourable way toward an entity. Generally, attitudes are the evaluation of ideas, event, objects or people that help in understanding and predicting the behaviour of individuals in different situations (Paluri and Mehra, 2016). An attitude is deemed relevant if it impacts greatly on basic social or personal value. The strength of an attitude therefore depends largely on the influence it has on behaviour. A weak attitude is one that can be easily changed and is unlikely to shape behaviour. On the other hand, attitudes that are the hardest to change are those that powerfully shape behaviour (Howe and Krosnick, 2017). Hence, attitude may become relevant if an individual views an attitude object as relevant to his basic social and personal values.

An individual's attitude toward financial matters has witnessed significant research interest for decades. Chowa et al. (2012) define financial attitude as an individual's beliefs and values related to the various financial concepts. Financial attitude has also been explained to mean the psychological tendency expressed when evaluating recommended financial management practices (Fernandes et al., 2014). Pham et al. (2012) surmise that attitude could be positive or negative depending on the motive of the individual. A positive attitude generally leads to a more desirable outcome, for instance responsible financial behaviour.

Financial management. Money management skills and the ability to make sound financial decisions through good financial management practices have been acknowledged by researchers to be extremely relevant to human success (Atkinson et al., 2006). Indeed, it has been argued that irrespective of an individual's financial status, it is important to practice financial management when making financial decisions or setting financial goals (Cámara and David, 2015; Parrotta and Johnson, 1998). The term "financial management" has been conceptualized to mean the process of planning, implementing and evaluating behaviour associated with the allocation of one's current flow of income as well as stock of wealth to meet financial goals and obligations (Godwin and Koonce, 1992). It includes activities such as cash flow, savings, investment, insurance, retirement planning, estate planning and tax planning among others. Managing one's financial affairs soundly is key to attaining financial satisfaction in life. Individuals with good financial management practices are unlikely to fall into financial troubles given that such individuals prioritize their spending, exhibit healthy financial behaviours such as saving for the future and planning for their retirement (Chinen and Endo, 2012).

In terms of the financial management and financial satisfaction nexus, a plethora of studies have confirmed that sound financial management impacts positively on financial
Predictors of financial satisfaction 
JHASS 5,1

\section{4}

satisfaction and life satisfaction in general (Cude et al., 2006; Davis and Weber, 1990; Kerkmann et al., 2000).

Conceptual framework. Figure 1 shows the conceptual framework developed for the study with reference to Davis and Helmick (1985). The framework, as shown in Figure 1, describes the relationships among the constructs used in the study. The study examines financial knowledge, financial attitude and financial management as determinants of financial satisfaction and psychological wellbeing, and as an outcome of financial satisfaction. Specifically, an individual's knowledge on financial issues is expected to influence their opinion, judgements or psychological evaluations about financial management practices (proxied by financial attitude). Financial attitude is expected to influence the individual to make use of recommended financial management practices such as basic money management, emergency savings and planning for retirement among others. It is expected that individuals engaging in this type of behaviour have greater chance of becoming financially satisfied in life. The peace of mind associated with being financially satisfied is expected to impact positively on the individual's psychological wellbeing.

Based on this conceptual framework, the following hypotheses will be tested:

H1. Financial knowledge has a positive relationship with financial satisfaction.

H2. Financial attitude has a positive relationship with financial satisfaction.

H3. Financial management has a positive relationship with financial satisfaction.

H4. Age, employment, gender, income and marital status are positively related with financial satisfaction.

H5. Financial satisfaction has a positive relationship with psychological wellbeing.

\section{Theoretical review}

The Deacon-Firebaugh model

The Deacon-Firebaugh model provides substantial theoretical grounding for this study. In determining the relationship between financial knowledge, attitude, management and financial satisfaction, a model in the form of a life cycle was developed, which stemmed from input, throughput and output.

Simply put, inputs enter the system and are transformed to produce outputs. The financial management literature generally defines inputs (which is the first stage of the process) to the system as material resources (such as income, net worth and savings), or as human resources (such as general education, age or financial knowledge). Outputs from the system have been commonly operationalized as objective outcomes such as change in net worth, or as

Figure 1.

Framework of the study

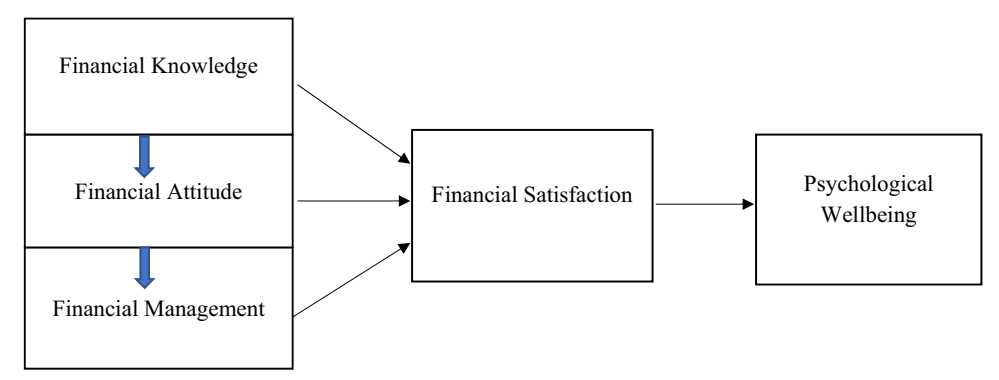


subjective outcomes such as satisfaction (Davis and Helmick, 1985; Hira and Mugenda, 1998). In this study, the outcome is proxied by satisfaction with financial status.

The second stage of the process, which is the system's throughput or transformation process, comprises the personal and managerial subsystems. The managerial subsystem is conventionally defined as money management practices or as planning and implementing behaviours. Consequently, the managerial subsystem is defined as financial management in this study, where financial management is the set of behaviours performed; specifically, the planning, implementing and evaluating involved in the areas of cash, credit, investments, insurance and retirement among others (Godwin and Koonce, 1992). The rationale for including attitudes in the personal subsystem is derived from combining the definition of attitudes in the psychological literature with Deacon and Firebaugh's definition of personal subsystem.

In extant psychological literature, attitude has been defined as "a psychological tendency that is expressed by evaluating a particular entity with some degree of favour or disfavour" (Eagly and Chaiken, 1993, p. 1). Therefore, financial attitudes can be considered as the psychological tendency expressed when evaluating recommended financial management practices with some degree of agreement or disagreement. Deacon and Firebaugh (1988) emphasize that values evolve, and cognitive, emotional, social and physical abilities develop in the personal subsystem. In Deacon and Firebaugh's discussion of the interactions of the personal and managerial subsystems, they posit that there is considerable exchange between the systems, with managerial actions both affecting and being affected by developmental capacities and evolving values. Eagly and Chaiken (1993) postulated that attitudes are manifested in behavioural responses. Therefore, it is reasonable to define financial attitudes as a personal subsystem variable and financial behaviours, which, in this instance, is financial management practices as a managerial subsystem variable.

\section{Methodology}

\section{Design, research instrument and data collection}

This study adopts the quantitative approach and data for study was collected by means of a structured questionnaire. The questionnaire consisted of two sections. The first section sought the demographic characteristics of the respondents while the second section sought the views of respondents on their level of financial satisfaction and the factors that influence their financial satisfaction using a seven-point Likert scale, where 1 represents a strong disagreement and 7 represents a strong agreement. Except for the psychological wellbeing scale that was adapted from The Hopkins Symptoms Checklist (HSCL), all scales used in this study were adapted from the work of Ali et al. (2015).

\section{Population, sample selection}

The population for this study consisted of all students pursuing post-graduate studies at the University of Ghana Business School. Post-graduate students were targeted for this study as the financial status of respondents is important in the financial satisfaction discourse. Given that the earning capacity of an individual is critical in assessing his/her financial status (Oquaye et al., 2020), post-graduate students were considered more ideal for this study as most undergraduate students are usually not in any form of gainful employment. To improve representativeness of the sample and to account for the differences in some key demographic characteristics of the respondents in the analysis, the questionnaires were administered during required core course sections for the students. Participation in the survey was voluntary and respondents were assured of confidentiality of their responses. A total of 386 questionnaires were administered in the second quarter of the year 2020, out of which 236 were returned: 217 valid responses were used for the analysis.
Predictors of financial satisfaction 
JHASS 5,1

66

As shown in Table 1, the sample size was male dominated, with $55.3 \%$ of the respondents being male, and most of the respondents were within the age bracket of 31-40 years. Approximately $63 \%$ of the respondents are married and a very significant number of the respondents $(90.3 \%)$ were employed.

\section{Descriptive statistics of constructs}

Table 2 presents the mean scores and the standard deviations of respondents' view on the various indicators used to measure the constructs. On average, the respondents were financially knowledgeable (Mean $=4.88$ ) and demonstrated a very positive attitude towards financial issues (Mean $=5.34$ ). Generally, the respondents expressed positive opinion and judgements when evaluating recommended financial management practices such as basic money management, credit planning and retirement planning, among others. Most of the respondents strongly share the view that it is necessary for an individual to plan his or her finances to ensure financial security.

The construct financial management had an overall mean score of 4.50, an indication that a considerable number of the respondents apply general principles of management in their financial decisions. The indicator "I actively invest in shares" recorded the lowest mean score (Mean $=3.34 ; \mathrm{SD}=2.04$ ) while the indicator "Before I buy something, I carefully consider whether I can afford it" recorded the highest mean score (Mean $=5.35 ; \mathrm{SD}=1.76$ ). Financial satisfaction recorded a mean score of 3.86. By implication, the respondents were moderately satisfied with their current financial situation. Out of the six indicators used to measure the financial satisfaction construct, the indicator "If I had a major loss of income, I could manage for a period of time" recorded the highest average score of 4.25 , while the indicator "I am satisfied with my current financial situation" recorded the lowest mean score of 3.45 .

\begin{tabular}{lcc}
\hline Variable & Frequency & Percentage \\
\hline Gender & & \\
Male & 120 & 55.3 \\
Female & 97 & 44.7 \\
Age & & \\
$21-30$ & 76 & 35 \\
11-40 & 112 & 51.6 \\
$41-50$ & 21 & 9.7 \\
51 and above & 8 & 3.6 \\
Marital status & & \\
Married & 136 & 62.7 \\
Unmarried & 81 & 37.3 \\
Monthly income & & \\
Below 1,000 & 7 & 3.2 \\
1,000-1999 & 56 & 25.8 \\
2000-2,999 & 50 & 23.0 \\
4,000-3,999 & 37 & 17.1 \\
5,000-4,999 & 24 & 11.1 \\
Employment status & 43 & 19.8 \\
Employed & & \\
Unemployed & 196 & 90.3 \\
& 21 & 9.7 \\
\hline
\end{tabular}

Table 1. 
Descriptive statistics of constructs

Financial knowledge

How would you rate your level of financial knowledge

Financial attitude

Individuals should concentrate on the present when managing their finances

Financial planning for retirement is not necessary for assuring one's security during old age

Having a financial plan makes it difficult to make financial investment decisions

Having a savings plan is not really necessary in today's world in order to meet one's financial needs

It is really essential to plan for the possible disability of a family wage earner

Planning is unnecessary distraction when individuals are just trying to get by today

Keeping records of financial matters is too time-consuming to worry about

Saving is not really important

It is important for an individual to develop a regular pattern of savings and stick to it Thinking about where you will be financially in 5 or 10 years in the future is essential for financial success

Overall mean

Financial management

I always pay bills before the due date

I always read the details of my bills to compare monthly usage or rate changes

I normally budget my monthly expenses

I keep track of my expenses

Before I buy something, I carefully consider whether I can afford it

On any day, I would know how much money I have to meet the daily living costs

I save money for retirement

My monthly pension contribution is sufficient for my retirement days

At any time, I have some money saved for emergencies

I ensure that with every pay, I would save some

I plan for long-term goals including children's education fund, houses and vehicles

My insurance coverage is sufficient to meet costs related to emergency events

I actively invest in shares

I have the right estate properties for my needs

I have proper estate planning for my heirs

I am currently following my long-term financial plan

Overall mean

\section{Financial satisfaction}

I am satisfied with my current financial situation

I can do little to improve my current financial situation

I rarely run short of money

Sometimes I feel that my income does not quite cover my living costs

If I had a major loss of income, I could manage for a period of time (e.g. for 3 months)

Based on my current financial situation, I could easily obtain a loan if I needed one

Overall mean
Std. deviation

Mean

4.88

1.31

5.16

5.69

5.65

5.61

5.82

5.62

6.00

4.30

4.71

4.86

5.34

Predictors of financial satisfaction

2.06

1.84

1.89

1.86

1.61

1.69

1.69

1.67

2.28

2.22

4.00

1.89

4.73

4.92

4.97

5.35

4.94

5.21

3.72

4.94

5.12

5.00

3.73

3.34

3.56

3.88

4.65

4.50

3.45

3.57

4.14

3.55

4.25

4.23

3.86
2.06

1.85

1.76

1.76

1.72

1.92

1.93

1.77

1.77

1.86

1.88

2.04

1.98

1.94

1.80

1.75

1.82

1.73

1.79

1.82

1.99

Table 2.

Descriptive statistics 
JHASS

5,1

Descriptive statistics of constructs

Std.

Psychological wellbeing

Frequent headaches

Feeling low in energy or slowed down

Difficulty in making decisions

Your mind going blind

Trouble concentrating

Feeling easily annoyed or irritated

Temper outburst you could not control

Suddenly scared for no reason

Poor appetite

Crying easily

Table 2.

Overall mean

5.42

5.00

4.97

5.26

4.88

4.72

4.88

4.94

4.94

5.05

5.01

deviation

$$
\begin{aligned}
& 1.69 \\
& 1.64 \\
& 1.70 \\
& 1.67 \\
& 1.73 \\
& 1.88 \\
& 1.89 \\
& 1.91 \\
& 1.87 \\
& 2.04
\end{aligned}
$$

The psychological wellbeing construct had an overall mean score of 5.01. With the mean score for the indicators of this construct ranging from 4.72 to 5.42 , it is a demonstration that most respondents are dissatisfied with their current financial status and are generally in a high state of psychological distress. Given that psychological wellbeing is usually conceptualized as a combination of positive affective states such as happiness, the high mean scores for each of the indicators (which are negatively worded) suggest high levels of stress arising from the respondents' dissatisfaction with their financial status.

\section{Construct reliability and validity tests}

Reliability and validity tests were conducted on the constructs to determine their suitability for inclusion in the structural model analysis. Reliability is the assessment of the consistency of results produced using a research instrument (Golafshani, 2003). The internal consistency of each construct was measured using the Cronbach alpha (CA) and composite reliability (CR) scores. Results of these tests, as shown in Table 3, indicate that the CA and CR score for each construct is above 0.70, which falls within the acceptable reliability range (Fornell and David, 1981) except for the financial satisfaction construct which recorded a CA value slightly below the minimum threshold.

Construct validity was assessed by means of the convergent and discriminant validity tests. Convergent validity was assessed using the average variance extracted (AVE). The AVE scores of all the constructs, as shown in Table 3, met the recommended threshold value of 0.5 and above (Hair et al., 2014). To show how distinct and uncorrelated the constructs are, the discriminant validity test was conducted using the Fornell-Larcker criterion. For discriminant validity to be assured, the square root of the AVE scores of the factors should be greater than the cross correlations between the factors (Fornell and David, 1981). Results of this test, as presented in Table 4, demonstrate that discriminant validity is assured as the AVE scores for the constructs were greater than the squared cross-correlations of the constructs.

\begin{tabular}{lccc}
\hline Factors & CA & CR & AVE \\
\hline Financial knowledge & 1.00 & 1.00 & 1.00 \\
Financial attitude & 0.71 & 0.81 & 0.53 \\
Financial management & 0.90 & 0.92 & 0.51 \\
Financial satisfaction & 0.68 & 0.80 & 0.51 \\
Psychological wellbeing & 0.94 & 0.95 & 0.63 \\
\hline
\end{tabular}

Table 3. 
Structural model analysis

Having established the suitability of the constructs by means of the reliability and validity tests, the study proceeded to assess the structural model. Prior to testing the hypotheses of the study, a multicollinearity test was conducted using the Variance Inflation Factor (VIF). VIF provides a reasonable and intuitive indication of the effects of multi-collinearity on the variance of a regression coefficient (O'Brien, 2007). Test results suggest the structural model analysis will not be influenced negatively by collinearity problems as the VIF values for the constructs fall within the recommended threshold having a lower bound of 1.00 and a higher bound of 1.42 (see Table 5).

The proposed hypotheses, as shown in Figure 2, were tested by employing the Smart-PLS Bootstrapping procedure. Results from the structural model analysis are presented in Table 6.

\section{Results and discussion}

The results, as shown in Table 6 , suggest a positive but insignificant relationship exists between financial knowledge and financial satisfaction $(\beta=0.062, p$-value $=0.311)$. The positive coefficient is an indication that the likelihood of becoming financially satisfied in life increases when an individual is knowledgeable in financial issues. Generally, individuals who are financially knowledgeable tend to interpret their financial circumstances better, have better coping mechanisms and always strive to improve their financial and living conditions (Joo and Grable, 2004; Hira and Mugenda, 1998). The insignificant result, however, suggests that financial knowledge may not be a key predictor of a person's financial satisfaction. As argued by Tang and Baker (2016), although financial knowledge is important, it is an insufficient driver of responsible financial behaviour and, by extension, financial satisfaction. While the evidence provided by extant studies is not conclusive, findings by most studies (Joo and Grable, 2004; Riitsalu and Murakas, 2019) generally conclude that knowledge is an important factor, but not the sole determinant of financial satisfaction. From the bootstrapping analysis, I also find sufficient evidence to support the claim that increased financial knowledge tends to be associated with a more positive financial attitude and responsible financial management behaviours.

The relationship between financial management and financial satisfaction yielded a positive and statistically significant relationship $(\beta=0.42, p$-value $=0.000)$. By implication, becoming financially satisfied in life also rests substantially on the ability to make sound financial decisions through good financial management practices. Thus, to be financially satisfied in life, an individual must be responsible in the way they deal with their daily financial routine and by saving and investment behaviours. Maintaining savings, investing rightly and planning for retirement are among the various responsible activities that must be undertaken to achieve financial satisfaction. Sound financial management behaviour indeed

\begin{tabular}{lcccrrr}
\hline Constructs & FA & FK & FM & FS & MS & PW \\
\hline FA & 0.73 & & & & & \\
FK & 0.11 & 1.00 & & & & \\
FM & 0.49 & 0.14 & 0.71 & & & \\
FS & 0.33 & 0.14 & 0.51 & 0.71 & & \\
MS & -0.08 & 0.01 & 0.00 & -0.05 & 1.00 & \\
PW & 0.39 & 0.16 & 0.37 & 0.28 & -0.02 & 0.80
\end{tabular}

Note(s): FA: Financial attitude, FK: Financial knowledge, FM: Financial management, FS: Financial satisfaction, MS: Marital status, PW: Psychological wellbeing

Predictors of financial satisfaction 
JHASS

5,1

Table 5.

VIF of indicators

\section{Constructs}

Financial knowledge

1.12

Financial attitude

1.35

1.35

1.42

Age

Employment

1.12

1.07

Gender

1.37

$\begin{array}{ll}\text { Marital status } & 1.21 \\ \text { Financial satisfaction } & 1.00\end{array}$
Figure 2.

A structural model of the relationship between the determinants of financial satisfaction and its impact on psychological wellbeing
Table 6.

Direct effects

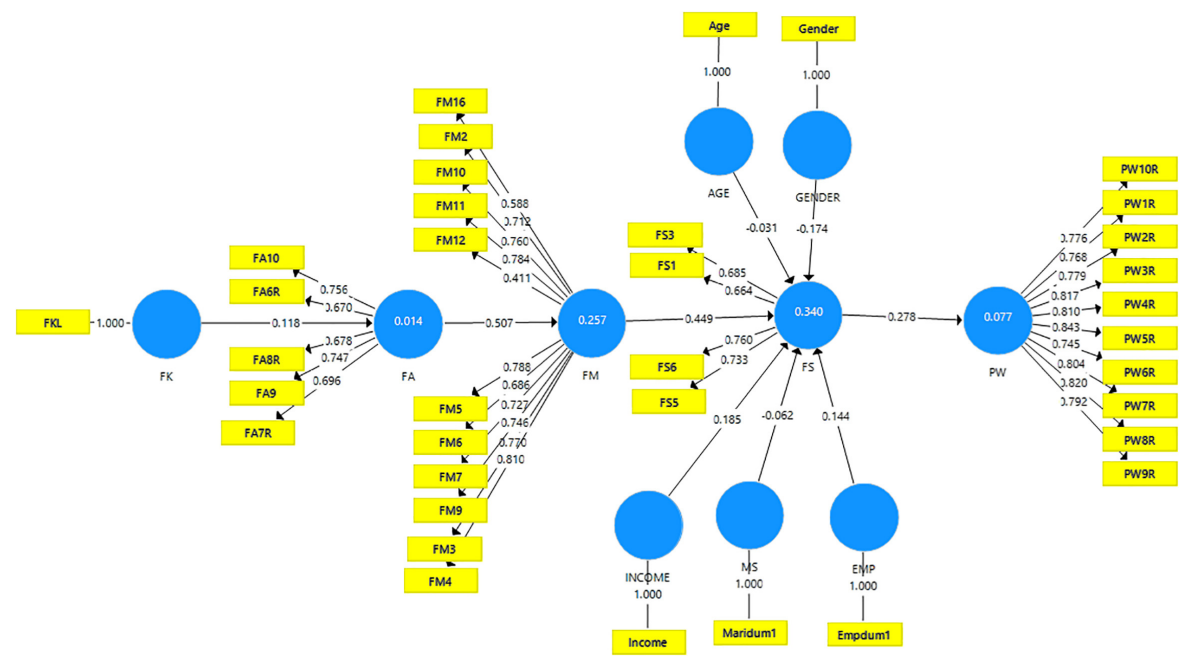

\begin{tabular}{lccl}
\hline Hypothesis path & Path coeff. & $p$-values & Remarks \\
\hline Financial knowledge $\rightarrow$ Financial attitude & 0.114 & 0.097 & Accepted \\
Financial attitude $\rightarrow$ Financial management & 0.500 & 0.000 & Accepted \\
Financial management $\rightarrow$ Financial satisfaction & 0.420 & 0.000 & Accepted \\
Financial knowledge $\rightarrow$ Financial management & 0.096 & 0.094 & Accepted \\
Financial attitude $\rightarrow$ Financial satisfaction & 0.108 & 0.135 & Not accepted \\
Financial knowledge $\rightarrow$ Financial satisfaction & 0.062 & 0.311 & Not accepted \\
Financial satisfaction $\rightarrow$ Psychological wellbeing & 0.277 & 0.000 & Accepted \\
Age $\rightarrow$ Financial satisfaction & -0.04 & 0.60 & Not accepted \\
Employment $\rightarrow$ Financial satisfaction & 0.14 & 0.02 & Accepted \\
Gender $\rightarrow$ Financial satisfaction & -0.17 & 0.01 & Accepted \\
Income $\rightarrow$ Financial satisfaction & 0.19 & 0.01 & Accepted \\
Marital status $\rightarrow$ Financial satisfaction & -0.06 & 0.31 & Not accepted \\
$R^{2}(0.34,0.07)$ & & & \\
$Q^{2}(0.15,0.04)$ & & & \\
\hline
\end{tabular}


reduces the risks of falling into financial problems, promotes prioritized spending behaviour and ultimately enhances the financial status of an individual and satisfaction thereof. This finding is consistent with results of prior studies (Baryła-Matejczuk et al., 2020; Qamar et al., 2016; Robb and Woodyard, 2011) that associate good financial management practices with financial satisfaction.

The results show a positive but insignificant relationship between financial attitude and financial satisfaction $(\beta=0.108, p$-value $=0.135)$. Thus, an individual's attitude, which describes the degree to which that individual evaluates a behaviour (financial) either favourably or unfavourably, may be a key determinant of the level of financial satisfaction. Positive attitude (tendency to act in a good or favourable way) towards financial matters is an important step in becoming financially satisfied in life, although the insignificant relationship suggests attitude alone does not determine behaviour (Paluri and Mehra, 2016). However, given that financial attitude has a positive and highly significant $(\beta=0.500, p$-value $=0.000)$ relationship with financial management behaviour, its implication on financial satisfaction cannot be overemphasized. This is because individuals with a good financial attitude tend to practice good personal financial management, which in the long run leads to improved financial satisfaction.

In terms of the association between the demographic variables and financial satisfaction, I find a positive and highly significant association between the employment status and income levels of the respondents and their financial satisfaction level. These findings suggest individuals in active employment tend to be more financially satisfied than the unemployed and that the higher the income level, the higher the likelihood of the individual becoming financially satisfied. As documented by some prior studies (Fan and Babiarz, 2019; Hsieh, 2003; Roszkowski and Goetz, 2019; Tharp et al., 2019), unemployment and the lack of regular income increases stress and decreases financial satisfaction of individuals. Furthermore, the results show a negative and statistically significant relationship between gender and financial satisfaction $(\beta=-0.17, p$-value $=0.00)$. This shows that gender differences significantly impact on an individual's financial satisfaction level. Interestingly, I find the females to be more financially satisfied than males in contrast with most empirical findings, which conclude that males are usually more financially satisfied than females (Kirbiš et al., 2017; Hira and Mugenda, 2000). Hira and Mugenda (2000), for instance, conclude that women are mostly dissatisfied with their financial situation as a result of indiscriminate spending habits.

On the other hand, age and marital status were found not to have any significant relationship with financial satisfaction. Intuitively, this demonstrates that a person's age does not significantly affect their financial satisfaction level. This finding is in sharp contrast with some existing studies (Ferrer-i-Carbonell and Frijters, 2004; Parrotta and Johnson, 1998; Ryff, 1995), which conclude that older generation tend to have more control of their environment, and have lower aspirations that are easier to meet; hence, are more financially satisfied as compared to the younger generation. However, it is consistent with the finding by Joo and Grable (2004) that demographic variables such as age may not directly influence financial satisfaction of people. The results $(\beta=-0.06, p$-value $=0.31)$ indicate that whether an individual is married or single does not significantly affect financial satisfaction. Thus, I did not find sufficient evidence to support findings by some extant studies (Yamokoski and Keister, 2006; Fan and Babiarz, 2019) that associate marital status with financial satisfaction.

Lastly, the results indicate a positive and highly significant relationship between financial satisfaction and psychological wellbeing $(\beta=0.277, p$-value $=0.000)$. Thus, consistent with my expectation, this finding demonstrates that individuals who are financially satisfied tend to be psychologically well in life. This means that individuals who are financially satisfied are more likely to be experiencing positive affective states such as happiness and are less likely to be experiencing negative affective states such as low energy, lack of concentration, temper
Predictors of financial satisfaction 
JHASS 5,1

outbursts, etc. Empirical evidence supports this finding that the satisfaction level of one's financial status greatly affects their psychological wellbeing (Archuleta et al., 2013; Plagnol, 2011; Creed and Watson, 2003; Kahneman and Deaton, 2010). Financial risk, attitude and financial behaviour have been taken to be the most important and consistent factors affecting financial satisfaction.

\section{2}

\section{Conclusion}

Financial satisfaction has been one of the topical issues discussed in the finance literature in recent times. Individuals as well as families are becoming more concerned about their financial health as it has been documented to have direct implications on their health, happiness and life satisfaction among others. Empirical studies on financial satisfaction have focused on discussing the determinants of financial satisfaction of households and how that impacts on their overall satisfaction in life. I contribute to the literature at the individual level by examining the predictors of financial satisfaction of individuals. Further, I examine the effect of financial satisfaction on the psychological wellbeing of individuals.

Findings of this study show that financial management is a good determinant of financial satisfaction. I also find financial knowledge and financial attitude to have a positive association with both financial management and financial satisfaction. Again, the results demonstrate that financial satisfaction impacts positively on an individual's psychological wellbeing. Taken together, these findings do not only show the relevance of financial satisfaction on an individual's psychological state but also suggest the mechanisms by which individuals can improve their level of financial satisfaction. Developing one's financial management skills is crucial to achieving financial satisfaction and the results show enhancing one's knowledge, and developing a positive financial attitude are some of the important means of promoting responsible financial management behaviour.

Notwithstanding the significant contributions of this study, the findings of this study are limited in some respects. The respondents used in this study were post-graduate business students who are expected to be more knowledgeable in financial matters than their peers pursuing non-business programmes. Future studies could consider a more diverse sample by focusing on both business and non-business students. Future research may also consider conducting a longitudinal cohort study to assess the changes in the financial satisfaction level of individuals over time.

\section{References}

Ali, A., Rahman, M.S.A. and Bakar, A. (2015), "Financial satisfaction and the influence of financial literacy in Malaysia”, Social Indicators Research, Vol. 120 No. 1, pp. 137-156.

Anic, P. and Tončić, M. (2013), "Orientations to happiness, subjective well-being and life goals", Psihologijske Teme, Vol. 22 No. 1, pp. 135-153.

Archuleta, K.L., Dale, A. and Spann, S.M. (2013), "College students and financial distress: exploring debt, financial satisfaction, and financial anxiety", Journal of Financial Counseling and Planning, Vol. 24 No. 2, pp. 50-62.

Atkinson, A., McKay, S., Collard, S. and Kempson, E. (2006), "Levels of financial capability in the UK", Public Money and Management, Vol. 27 No. 1, pp. 29-36.

Baryła-Matejczuk, M., Skvarciany, V., Cwynar, A., Poleszak, W. and Cwynar, W. (2020), "Link between financial management behaviours and quality of relationship and overall life satisfaction among married and cohabiting couples: insights from application of artificial neural networks", International Journal of Environmental Research and Public Health, Vol. 17 No. 4, p. 1190.

Blatný, M. and Šolcová, I. (2016), "Personality and well-being", Ceskoslovenska Psychologie, Vol. 60 No. 3, pp. 2-12. 
Bowen, C.F. (2002), "Financial knowledge of Teens and their parents", Financial Counseling and Planning, Vol. 13 No. 2, pp. 93-102.

Cámara, N. and David, T. (2015), "Factors that matter for financial inclusion: evidence from Peru", Aestimatio, Vol. 9, pp. 8-29.

Carmeli, A., Yitzhak-Halevy, M. and Weisberg, J. (2009), "The relationship between emotional intelligence and psychological wellbeing”, Journal of Managerial Psychology, Vol. 24 No. 1, pp. 66-78.

Chinen, K. and Endo, H. (2012), "Effects of attitude and background on students' personal financial ability: a United States survey”, International Journal of Management, Vol. 29 No. 2, pp. 778-791.

Chowa, G.A.N., Despard, M. and Osei-Akoto, I. (2012), "Financial knowledge and attitudes of youth in Ghana”, Youthsave Research Brief, Vol. 2, pp. 12-37.

Creed, P.A. and Watson, T. (2003), "Age, gender, psychological wellbeing and the impact of losing the latent and manifest benefits of employment in unemployed people", Australian Journal of Psychology, Vol. 55 No. 2, pp. 95-103.

Cude, B., Lawrence, F., Lyons, A., Metzger, K., LeJeune, E., Marks, L. and Machtmes, K. (2006), "College students and financial literacy: what they know and what we need to learn", Eastern Family Economics and Resource Management Association, Vol. 102 No. 9, pp. 106-109.

Davis, E.P. and Helmick, S.A. (1985), "Family financial satisfaction: the impact of reference points", Home Economics Research Journal, Vol. 14 No. 1, pp. 123-131.

Davis, E.P. and Weber, J.A. (1990), "Patterns and obstacles to financial management", Financial Counseling and Planning, Vol. 1 No. 402, pp. 41-52.

Deacon, R.E. and Firebaugh, F.M. (1998), Family Resource Management: Principles and Applications, 2nd ed., Allyn and Bacon, Boston, MA.

Derogatis, L.R., Lipman, R.S., Rickels, K., Uhlenhuth, E.H. and Covi, L. (1974), "The Hopkins symptom checklist (HSCL): a self report symptom inventory”, Behavioral Science, Vol. 19, pp. 1-15.

Eagly, A. and Chaiken, S. (1993), "The psychology of attitudes", Psychology and Marketing, Vol. 12 No. 5 , pp. 459-466.

Erskine, H. (1973), "The polls: hopes, fears and regrets", American Association for Public Opinion Reserach, Vol. 37 No. 1, pp. 132-145.

Fan, L. and Babiarz, P. (2019), "The determinants of subjective financial satisfaction and the moderating roles of gender and marital status", Family and Consumer Sciences Research Journal, Vol. 47 No. 3, pp. 237-259.

Felce, D. and Perry, J. (1995), "Quality of Life: its definition and measurement", Research in Developmental Disabilities, Vol. 16 No. 1, pp. 51-74.

Fernandes, D., Lynch, J.G. and Netemeyer, R.G. (2014), "Financial literacy, financial education and Downstream financial behaviours", Management Science Journal, Vol. 60 No. 8, pp. 1861-2109, iv-vii.

Ferrer-i-Carbonell, A. and Frijters, P. (2004), "How important is methodology for the estimates of the determinants of happiness?", Economic Journal, Vol. 114 No. 497, pp. 641-659.

Fornell, C. and David, L.F. (1981), "Structural equation models with unobservable variables and measurement error", Algebra and Statistics, Vol. 18 No. 3, pp. 382-388.

Godwin, D.D. and Koonce, J.C. (1992), "Cash flow management of low-income newlyweds", Financial Counseling and Planning, Vol. 3, pp. 17-42.

Golafshani, N. (2003), "Understanding reliability and validity in”, Qualitative Research, Vol. 8 No. 4, pp. 597-606.

Hair, J.F., Sarstedt, M., Hopkins, L. and Kuppelwieser, G.V. (2014), "Partial least squares structural equation modeling (PLS-SEM)", European Business Review, Vol. 26 No. 2, p. 26.

Hansen, T., Slagsvold, B. and Moum, T. (2008), "Financial satisfaction in old age: a satisfaction paradox or a result of accumulated wealth?", Social Indicators Research, Vol. 89 No. 2, pp. 323-347. 
JHASS 5,1

Hernandez, R., Bassett, S.M., Boughton, S.W., Schuette, S.A., Shiu, E.W. and Moskowitz, J.T. (2018), "Psychological well-being and physical health: associations, mechanisms, and future directions", Emotion Review, Vol. 10 No. 1, pp. 18-29.

Hira, K.T. and Mugenda, O.M. (1998), "Predictors of financial satisfaction: differences between retirees and non-retirees", Financial Counseling and Planning, Vol. 9 No. 2, pp. 75-84.

Hira, T.K. and Mugenda, O. (2000), "Gender differences in financial perceptions, behaviours and satisfaction”, Journal of Financial Planning-Denver, Vol. 13 No. 2, pp. 86-93.

Hong, G.-S. and Swanson, P.M. (1995), "Comparison of financial well-being of older women: 1977 and 1989", Journal of Financial Counseling and Planning, Vol. 6 No. 317, pp. 129-138.

Howe, L.C. and Krosnick, J.A. (2017), “Attitude strength”, Annual Review of Psychology, Vol. 68, pp. 327-351.

Hsieh, C. (2003), "Income and financial satisfaction among older adults in the United States", Social Indicators Research, Vol. 66 No. 3, pp. 249-266.

Huston, S.J. (2010), "Measuring financial literacy", The Journal of Consumer Affairs, Vol. 44 No. 2, pp. 296-316.

ILO (2018), Ensuring Decent Working Time for the Future.

Ingrid, B., Majda, R. and Dubravka, M. (2009), "Life goals and well-being: are extrinsic aspirations always detrimental to well-being?”, Psychological Topics, Vol. 18 No. 2, pp. 317-334.

Joo, S.H. and Grable, J.E. (2004), "An exploratory framework of the determinants of financial satisfaction", Journal of Family and Economic Issues, Vol. 25 No. 1, pp. 25-50.

Kahneman, D. and Deaton, A. (2010), "High income improves evaluation of life but not emotional wellbeing", Proceedings of the National Academy of Sciences, Vol. 107 No. 38, pp. 16489-16493.

Kalra Sahi, S. (2013), "Demographic and socio-economic determinants of financial satisfaction: a study of SEC-A segment of individual investors in India”, International Journal of Social Economics, Vol. 40 No. 2, pp. 127-150.

Kerkmann, B.C., Lee, T.R., Lown, J.M. and Allgood, S.M. (2000), "Financial management, financial problems and marital satisfaction among recently married university students", Financial Counseling and Planning, Vol. 11 No. 2, pp. 55-65.

Kim, J. and Chatterjee, S. (2019), "Student loans, health, and life satisfaction of US households: evidence from a panel study", Journal of Family and Economic Issues, Vol. 40 No. 1, pp. 36-50.

Kirbiš, I.Š., Vehovec, M. and Galić, Z. (2017), "Relationship between financial satisfaction and financial literacy: exploring gender differences”, Društvena Istraživanja, Vol. 26 No. 2, pp. 165-185.

Korankye, T. and Kalenkoski, C.M. (2021), "The effect of households' student debt on life satisfaction”, Journal of Family and Economic Issues, pp. 1-16.

Lester, D., Hvezda, J., Sullivan, S. and Plourde, R. (1983), "Maslow's hierarchy of needs and psychological health", The Journal of General Psychology, Vol. 109 No. 1, pp. 83-85.

$\mathrm{Ng}, \mathrm{W}$. and Diener, E. (2014), "What matters to the rich and the poor? Subjective well-being, financial satisfaction, and postmaterialist needs across the world", Journal of Personality and Social Psychology, Vol. 107 No. 2, p. 326.

Oishi, S., Diener, E., Lucas, R.E. and Suh, E.M. (2009), "Cross-cultural variations in predictors of life satisfaction: perspectives from needs and values", in Culture and Well-Being, Springer, Dordrecht, pp. 109-127.

Oquaye, M., Owusu, G.M.Y. and Bokpin, G.A. (2020), "The antecedents and consequence of financial well-being: a survey of parliamentarians in Ghana”, Review of Behavioral Finance. doi: 10.1108/ RBF-12-2019-0169.

O'Brien, R.M. (2007), “A caution regarding rules of thumb for variance inflation factors”, Quality and Quantity, Vol. 41 No. 5, pp. 673-690.

Paluri, R.A. and Mehra, S. (2016), "Financial attitude based segmentation of women in India: an exploratory study", International Journal of Bank Marketing, Vol. 34 No. 5, pp. 670-689. 
Parrotta, J.L. and Johnson, P.J. (1998), "The impact of financial attitudes and knowledge on financial management and satisfaction of recently married individuals", Journal of Financial Counseling and Planning, Vol. 9 No. 2, pp. 59-75.

Pham, T.H., Yap, K. and Dowling, N.A. (2012), "The impact of financial management practices and financial attitudes on the relationship between materialism and compulsive buying", Journal of Economic Psychology, Vol. 33 No. 3, pp. 461-470.

Plagnol, A.C. (2011), "Financial satisfaction over the life course: the influence of assets and liabilities", Journal of Economic Psychology, Vol. 32 No. 1, pp. 45-64.

Plouffe, R.A. and Tremblay, P.F. (2017), "The relationship between income and life satisfaction: does religiosity play a role?", Personality and Individual Differences, Vol. 109, pp. 67-71.

Qamar, M.A.J., Khemta, M.A.N. and Jamil, H. (2016), "How knowledge and financial self-efficacy moderate the relationship between money attitudes and personal financial management behaviour", European Online Journal of Natural and Social Sciences, Vol. 5 No. 2, p. 296.

Riitsalu, L. and Murakas, R. (2019), "Subjective financial knowledge, prudent behaviour and income: the predictors of financial well-being in Estonia", International Journal of Bank Marketing, Vol. 37 No. 4, pp. 934-950.

Robb, C.A. and Woodyard, A.S. (2011), "Financial knowledge and best practice behaviour", Journal of Financial Counseling and Planning, No. 205, pp. 60-70.

Roszkowski, M.J. and Goetz, J.W. (2019), "The relationship between salary and perceived financial comfort among graduates of a developmental education program", Research and Teaching in Developmental Education, Vol. 26 No. 1, pp. 10-18.

Ryff, C.D. (1995), "Psychological well-being in adult life", Current Directions in Psychological Science, Vol. 4 No. 4, pp. 99-104.

Ryff, C.D. and Singer, B. (1996), "Psychological well-being: meaning, measurement, and implications for psychotherapy research", Psychotherapy and Psychosomatics, Vol. 65 No. 1, pp. 14-23.

Sam, D.L., Tetteh, D.K. and Amponsah, B. (2015), "Satisfaction with life and psychological symptoms among international students in Ghana and their correlates", International Journal of Intercultural Relations, Vol. 49, pp. 156-167.

Seghieri, C., Desantis, G. and Tanturri, M.L. (2006), "The richer, the happier? An empirical investigation in selected European countries", Social Indicators Research, Vol. 79 No. 3, pp. 455-476.

Servon, L.J. and Kaestner, R. (2008), "Consumer financial literacy and the impact of online banking on the financial behaviour of lower-income bank customers", Journal of Consumer Affairs, Vol. 42 No. 2, pp. 271-305.

Tang, N. and Baker, A. (2016), "Self-esteem, financial knowledge and financial behaviour", Journal of Economic Psychology, Vol. 54, pp. 164-176.

Tharp, D.T., Seay, M., Stueve, C. and Anderson, S. (2019), "Financial satisfaction and homeownership", Journal of Family and Economic Issues, Vol. 41 No. 2, pp. 255-280.

Vera-Toscano, E., Ateca-Amestoy, V. and Serrano-del-Rosal, R. (2006), "Building financial satisfaction”, Social Indicators Research, Vol. 77 No. 2, pp. 211-243.

Vlaev, I. and Elliott, A. (2013), "Financial well-being components", Social Indicators Research, Vol. 18 No. 3, pp. 1103-1123.

Xiao, J.J. and Porto, N. (2017), "Financial education and financial satisfaction: financial literacy, behaviour, and capability as mediators", International Journal of Bank Marketing, Vol. 35 No. 5, pp. 805-817.

Xiao, J.J., Tang, C. and Shim, S. (2009), "Acting for happiness: financial behaviour and life satisfaction of college students", Social Indicators Research, Vol. 92 No. 1, pp. 53-68.

Yamokoski, A. and Keister, L.A. (2006), "The wealth of single women: marital status and parenthood in the asset accumulation of young baby boomers in the United States", Feminist Economics, Vol. 12 Nos 1-2, pp. 167-194.

Predictors of financial satisfaction 
JHASS

5,1

Zemtsov, A.A., Osipova, T.Y. and Osipova, T. (2015), "Financial wellbeing as a type of human wellbeing: theoretical review", The European Proceedings of Social and Behaviour Sciences, Vol. 7, pp. 385-392.

Zika, S. and Chamberlain, K. (1992), "On the relation between meaning in life and psychological wellbeing”, British Journal of Psychology, Vol. 83 No. 1, pp. 133-145.

Godfred Matthew Yaw Owusu can be contacted at: gmowusu@gmail.com

For instructions on how to order reprints of this article, please visit our website: www.emeraldgrouppublishing.com/licensing/reprints.htm Or contact us for further details: permissions@emeraldinsight.com 